\title{
THE EFFECT OF CORONA INCANDESCENT PLASMA RADIATION AND STORAGE TEMPERATURE ON THE VIABILITY OF GARLIC SEEDS (ALLIUM SATIVUM L. LUMBU KUNING VARIETY)
}

\author{
Febiasasti Trias Nugraheni ${ }^{*}{ }_{1}$, Erma Prihastanti ${ }^{* 2}{ }^{\boxplus}$, Endah Dwi Hastuti ${ }^{* 3}$ \\ ${ }^{*} 1,{ }^{*} 2,{ }^{*} 3$ Department of Biology, Faculty of Science and Mathematics, Diponegoro University, \\ Semarang, Jl. Prof. Soedarto, SH Tembalang, Semarang, Indonesia
}

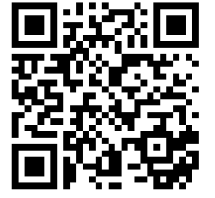

DOI: https://doi.org/10.29121/IJOEST.v5.i1.2021.149

Article Type: Research Article

Article Citation: Febiasasti Trias Nugraheni, Erma Prihastanti, and Endah Dwi Hastuti. (2021). THE EFFECT OF CORONA INCANDESCENT PLASMA RADIATION AND STORAGE TEMPERATURE ON THE VIABILITY OF GARLIC SEEDS (ALLIUM SATIVUM L. LUMBU KUNING VARIETY). International Journal of Engineering Science Technologies, 5(1), 11-17.

https://doi.org/10.29121/IJOEST.v 5.11.2021.149

Received Date: 01 January 2021

Accepted Date: 31 January 2021

Keywords:

Garlic Seeds

Dormancy

Plasma Radiation

Storage Temperature

Viability

\section{ABSTRACT}

Garlic (Allium sativum L.) is an agricultural commodity which is widely consumed by the community. The obstacle experienced in cultivation is that a relatively long dormancy period of about 6-7 months. The dormancy of garlic seeds occurs because the embryo has not yet been fully formed, and the growth hormone and inhibitory hormone are not balanced. The methods used to break dormancy and accelerate germination are by using corona incandescent plasma radiation and storage temperature. The research utilized factorial Completely Randomized Design (CRD), consisting of six treatments with five replications. The first factor was the corona incandescent plasma radiation carried out on the garlic seeds 'Lumbu Kuning' variety with time duration of 0,15 , and 30 minutes. The second factor was storage temperature comprising of room temperature and cold temperature of $7 \mathrm{oC}$ stored for 30 days. Viability parameters observed are germination percentage dan the length of sprouts. The data were analyzed by using ANOVA followed by the DMRT test at the 95\% confidence level. The results showed that corona incandescent plasma radiation influenced the germination percentage using plasma radiation for $15-30$ minutes.

\section{INTRODUCTION}

Garlic (Allium sativum L.) is an agricultural commodity in Indonesia that has high economic value, has many benefits for health, is used as cooking spices, and as beauty. In Indonesia, the need for garlic is extremely large, but it is not balanced with the amount of production. As a result, imports occur to support people's needs. The selfsufficiency program is carried out to increase garlic production on a large scale, but there are major problems in cultivation, namely the seeds have low viability and quality, and experience dormancy for about 6-7 months (Rahman, Haque, \& Ahmed, 2003). Based on Indonesian National Standard (SNI) number 01-3160-1992, highquality garlic is a garlic plant which consists of pithy cloves, unified, is still covered with outer skin, clean, and not

(C) 2021 The Author(s). This is an open access article distributed under the terms of the Creative Commons Attribution License, which permits unrestricted use, distribution, and reproduction in any medium, provided the original author and source are credited. 
The Effect of Corona Incandescent Plasma Radiation and Storage Temperature on The Viability of Garlic Seeds (Allium Sativum L. Lumbu Kuning Variety)

moldy. The base of the tuber is full and hard, has large cloves, the cloves weight of garlic seeds used is between 1.15 - 3 g [(Wicaksono, Rahayu, \& Samanhudi, 2014).

Dormancy occurs because the embryo is not fully formed, the growth inhibiting hormone (abscisic acid) is not balanced with the growth regulating hormone (gibberellin), germination genes are not actively expressed (Shu, Liu, Xie, \& He, 2016)]. Growth regulating hormones have roles in germination, such as auxin, gibberelin, and cytokinin (Zhao, 2010). Abscisic acid (ABA) is an inhibiting hormone that has a role to regulate dormancy (Yeol, Warpeha, \& Huber, 2019). Seeds dormancy is caused by germination genes that are not actively expressed causing the seeds do not undergo cell division and elongation, there is no mobilization of nutrients, consequently, the radicles do not penetrate the testa and endosperm (Shu et al., 2016). The chromatin structure determines the expression of genes that regulate seed dormancy and germination (Zheng et al., 2012). Dormancy is related to the chromatin and chromosome structure in the seed, where germination genes cannot be activated, so that transcription has steric hindrance. Conversely, dormancy breaking occurs when the chromatin structure is modified by cold stratification, and makes germination genes active for transcription, so that cell extension and division occurs, endosperm can develop and penetrate the seed coat, eventually radicles appear when conditions are favorable. This suggests that the abscisic acid hormone synthesized by the seeds plays a role in dormancy (Kucera, Cohn, \& Leubner-metzger, 2005). The abundance of Endogenous Abscisic Acid (ABA) correlating closely with seed dormancy inhibits germination by increasing the expression of negative regulators, thereby, delaying the seeds to produce radicle (Graeber et al., 2010). Seeds that are deficient in ABA due to mutation or chemical treatment will show decreased dormancy and increased germination. Gibberellins break dormancy and regulate seed germination by stimulating the secretion of hydrolytic enzymes, thereby, weakening inhibitory tissue, such as seed coat (Holdsworth, Bentsink, \& Soppe, 2008). Cytokinins, as growth hormone, stimulates protein synthesis, plays a role in cell cycle control, stimulates cell division activity and is extremely effective in icreasing sprout initiation (Rosniawaty, Anjarsari, \& Sudirja, 2018). Dormancy that occurs in garlic causes garlic to take more than three months with environmental temperature and relative humidity storage in order that the spout grows uniformly. During storage, sucrose and starch are used with high content and the part of carbohydrates that is not consumed causes glucose to accumulate in the tissues, thereby supporting growth (Woldeyes, Kebede, \& Tabor, 2017).

Pre-treatment using corona incandescent plasma radiation and storage temperature can be used to break the dormancy of garlic seeds, so that it results in high-quality seeds. High-quality seeds can be seen from the viability and vigor of the seeds which are characterized by high germination and fast, synchronous, as well as uniform growth (Sari \& Faisal, 2017). Seed viability is the ability of the embryo to germinate, and is influenced by a number of different conditions; meanwhile, seed vigor is the strength of the seed which is defined as the total number of seed characteristics that will determine the level of activity and performance of the seed during germination and emergence of the seed. If the seed loses vigor, it will affect the ability of the seeds to carry out all physiological functions, because it will allow changes in cell membrane integrity, enzyme activity, and protein synthesis. Consequently, it can result in seed death (Shaban, 2013). The germination test or seed growth rate and germination rate are tested to detect seed viability parameter. A germination rate of more than $85 \%$ indicates a high growth strength, while less than 50\% indicates low growth strength (Sulassih, Purwanto, Naibaho, Pratama, \& Nurmalia, 2018).

The methods used to break dormancy and increase the viability of garlic seeds are CAPP '(Cold atmosphericpressure plasma)' and storage temperature. Plasma radiation or CAPP '(Cold atmospheric-pressure plasma)' is one of the most inventive methods of handling seeds (Kordas, Pusz, Czapka, \& Kacprzyk, 2015). Plasma is a partially ionized gas which contains molecules, electrons, ions, atoms and free radicals. A wide variety of microorganisms including spores can be inactivated by plasma. Corona discharge is one of the phenomena of cold plasma which is produced by separating electrons from molecules (ionization) due to the high voltage between two electrodes. The release of the corona appears as light in a localized space around the tip of the point (Zhou et al., 2016). Corona incandescent plasma radiation is also called 'Cold atmospheric-pressure plasma' (CAPP) is an ionized gas that comes from atmospheric pressure, containing charged particles (electrons, ions) and neutral particles (atoms, molecules) and photons. Plasma which produces reactive oxygen species (ROS) and reactive nitrogen (RON) include $\mathrm{NOx}, \mathrm{OH}$, 0 , and 03. The majority of RONS produced by plasma jet is unstable. The most common and the most relative stable products are the HNO2, HNO3, H2O2, $\mathrm{O3}$ and NOx compounds (Volkov, Hairston, Patel, Ryan, \& Xu, 2019).

The N2 molecule from the atmosphere is inert, so that it cannot be utilized by most organisms. Therefore, the $\mathrm{N} 2$ molecule must firstly be converted into a reactive form (such as ammonia or nitrate) through the nitrogen fixation 
Febiasasti Trias Nugraheni, Erma Prihastanti, and Endah Dwi Hastuti

process in the form of NOx. Plasma reactors fix nitrogen from the air by breaking down $\mathrm{N} 2$ and 02 molecules in the air into $\mathrm{N}$ and $\mathrm{O}$ atoms which form nitrogen oxides (nitric acid or ammonia). The overall reaction for NOx production is $\mathrm{N} 2+\mathrm{O} 2 \leftrightarrow 2 \mathrm{NO}$ (Ling et al., 2016). This process occurs by breaking the triple bond of $\mathrm{N} 2$ and the bonding of the $\mathrm{N}$ atom with other elements such as oxygen, hydrogen or carbon (Li, Jimenez, Hessel, \& Gallucci, 2018). Ammonia can be synthesized with the help of H2O. The presence of $\mathrm{H} 2 \mathrm{O}$ gas has an effect on ammonia production. Formation of nitrite (NO2-) and nitrate (NO3-) is through the degradation of NOx from the reaction of N2 and 02 or $\mathrm{H} 2 \mathrm{O}$ gases that are dissociated (Zhou et al., 2016). Nitric oxide (NO·) is known to break dormancy and increase germination, depending on crosstalk with abscisic acid signaling network (ABA). The effect of plasma on seed characteristics can also increase the hydrophilic ability of the seeds to increase water absorption. plasma treatment for 60 seconds on mulungu seeds (Erythrina velutina) had a greater effect on germination, water absorption, seed permeability and seed structure than the untreated seed group (Junior, Vitoriano, Silva, Farias, \& Dantas, 2016).

During seed dormancy, abscisic acid (ABA) levels are high and will decrease with warm or cold stratification, and gibberellin levels increase after cold stratification or vernalization (Lewak, 2011). Cold stratification can break seed embryo dormancy through catabolism of lipid, sugar, and protein by hydrolytic or proteolytic enzymes, regulate seed germination by activating hydrolase, protein catabolization, and the number of amino acids to increase, break dormancy by increasing starch content (Chen et al., 2015). The objective of this study was to prove the treatment of corona incandescent plasma radiation and storage temperature on the viability of garlic seeds (Allium sativum L.) 'Lumbu Kuning' Variety, especially breaking dormancy which can be cultivated with a relatively short age and produce higher quality production.

\section{MATERIALS AND METHODS}

Garlic Seeds Preparation: It was used garlic seeds of 'Lumbu kuning' variety aged 3 months post-harvest. They were obtained from from garlic farmers in Temanggung, Parakan District, Central Java, Indonesia. Garlic seeds were sorted according to size and uniform weight. The tubers were separated into several cloves weighing 1.5-2 g per clove.

Storage Temperature: Prepared seeds were stored in different temperatures. There were room temperature and a cold temperature of $7^{\circ} \mathrm{C}$ for 1 month (Sulassih et al., 2018). Furthermore, plasma radiation was conducted using a corona incandescent.

Corona discharge plasma jet generation: The garlic seeds that have been stored at room temperature and cold temperature for 1 month are then taken to the Plasma Laboratory of the Physics Department, Faculty of Science and Mathematics, Diponegoro University to be irradiated with corona incandescent plasma. Plasma was generated with source voltage $11 \mathrm{~V}$ DC current $50 \mathrm{~mA}$. The distance was $3 \mathrm{~cm}$ from the electrode unit and the sample plate. The seeds were placed on the sample plate with the seed base at the top, without peeling the garlic seed coat. The plasma reactor could accommodate of 60 garlic seeds in one radiation. Three radiation treatments were used: treatment $A$ (control) treatment B (radiation for 15 minutes), treatment C (radiation for 30 minutes).

Planting Seeds: The seeds that had given radiation treatment in room temperature and cold temperature of $7^{\circ} \mathrm{C}$ was conducted planting seeds without peeling the skin in a polybag size $30 \times 30$ containing soil media, husks, manure in a ratio of 2: $1: 1$. Each polybag contained 10 seeds, repeated 5 times. Planting is carried out on a highland with an altitude of 900 above sea level in Semarang, Central Java, Indonesia.

Measurement of percentage and rate of of germination: The percentage of germination of seeds was determined by counting the number of seeds that germinate normally every day for a period of 2 weeks, or after one of the treatments can germinate $100 \%$. Based on (Sulassih et al., 2018) the formula for seed growth power is as follows:

$$
\text { Germination Percentage }=\frac{\text { The number of germinated }}{\text { the number of seeds that are germinated }} \times 100 \%
$$

Germination rate is determined by counting the number of days it takes for the emergence of radicle or plumule over a certain period of time ( 2 weeks). The germination rate is calculated by using the formula (Lesilolo, Riry, \& Matatula, 2013): 
The Effect of Corona Incandescent Plasma Radiation and Storage Temperature on The Viability of Garlic Seeds (Allium Sativum L. Lumbu Kuning Variety)

Where:

$$
\mathrm{GR}=\frac{\mathrm{N} 1 \mathrm{~T} 1+\mathrm{N} 2 \mathrm{~T} 2+\cdots+\mathrm{NxTx}}{\mathrm{JB}}
$$

$\mathrm{LP}=$ Germination rate

$\mathrm{N}=$ The number of seeds germinating in a certain unit of time,

$\mathrm{T}=$ The amount of time between the initial test and the final test at a certain interval of

observation,

$$
\mathrm{JB}=\text { Number of seeds germinating. }
$$

Data Analysis: The data that had been obtained were analyzed using SPSS software with (ANOVA) univariate 2 factors and followed by the DMRT test (Duncan's multiple range test (DMRT)).

\section{RESULT AND DISCUSSION}

Effect Corona Fluorescent Plasma Radiation and Storage Temperature on Germination Percentage and the length of sprouts.

The results of Analysis of Variance (ANOVA) showed a significant difference value $(\mathrm{P}<0.05)$ in the corona incandescent plasma radiation treatment. While the storage temperature treatment showed no significant difference $(P>0.05)$. The interaction between corona fluorescent plasma radiation and storage temperature was not significantly different $(\mathrm{P}>0.05)$ (Table 1 and table 2 ).

Table 1: Percentage Germination of Garlic Seed after Treatment

\begin{tabular}{|c|c|c|c|}
\hline \multirow{2}{*}{$\begin{array}{c}\text { Plasma Radiation } \\
(\mathrm{R})\end{array}$} & \multicolumn{2}{|c|}{ Temperature (T) } & Average \\
\cline { 2 - 3 } & $\mathrm{T}_{1}$ & $\mathrm{~T}_{2}$ & \\
\hline $\mathrm{R}_{0}$ & 40,00 & 44,00 & $42,00^{\mathrm{b}}$ \\
\hline $\mathrm{R}_{1}$ & 88,00 & 54,00 & $71,00^{\mathrm{a}}$ \\
\hline $\mathrm{R}_{2}$ & 78,00 & 70,00 & $74,00^{\mathrm{a}}$ \\
\hline Average & 68,67 & 65,00 & $(-)$ \\
\hline
\end{tabular}

Information: numbers in rows and columns followed by the same letter show that there is no difference at the significant level $(\alpha) 5 \%$

Based on the DMRT test. $(-)=$ There is no interaction between factors.

Tabel 2: Length of the sproutsPlasma Radiation

\begin{tabular}{|c|c|c|c|}
\hline $\begin{array}{c}\text { Plasma Radiation } \\
\text { (R) }\end{array}$ & \multicolumn{2}{|c|}{ Temperature (T) } & Average \\
\cline { 2 - 3 } & $\mathrm{T}_{1}$ & $\mathrm{~T}_{2}$ & \\
\hline $\mathrm{R}_{0}$ & 7,8 & 6,6 & $7,19 \mathrm{~b}$ \\
\hline $\mathrm{R}_{1}$ & 14,5 & 11,4 & $12,97^{\mathrm{a}}$ \\
\hline $\mathrm{R}_{2}$ & 12,2 & 7,2 & $9,6^{\mathrm{b}}$ \\
\hline Average & 11,5 & 8,4 & $(-)$ \\
\hline
\end{tabular}

Information: numbers in rows and columns followed by the same letter show that there is no difference at the significant level $(\alpha) 5 \%$

Based on the DMRT test. $(-)=$ There is no interaction between factors.

The factor of plasma radiation had a significant effect on the percentage of garlic sprouting at 15 minutes (R1) and 30 minutes (R2) of radiation. 30-minute radiation showed the highest percentage of germination at $74.00 \%$. The longer the radiation, the higher the germination percentage will be; while the optimal storage temperature is at room temperature. Plasma radiation for 30 minutes (R2) had moderate growth power, but was the highest among other treatments. The Indonesia National Standard (SNI) value stipulated for the quality of seeds in labeled packaging is $70-80 \%$ depending on the type of seed (Lesilolo et al., 2013), but seed growth vigor that has a value of more than $85 \%$ indicates an extremely high vigor growth; while less than $50 \%$ indicates a low vigor growth strength. 
Febiasasti Trias Nugraheni, Erma Prihastanti, and Endah Dwi Hastuti

Plasma radiation factor had a significant effect on the length of sprouts at 15 minutes (P1) and 30 minutes (P2) of radiation. 15 minutes radiation showed the highest sprouts length of 12.97 , while 0 minutes radiation showed the lowest sprouts length of 7.19.

Plasma radiation for 30 minutes is the optimal duration to accelerate garlic germination. Plasma radiation or CAPP '(Cold atmospheric-pressure plasma)' is one of the most inventive methods of handling seeds (Volkov et al., 2019) which produces reactive oxygen (ROS) and reactive nitrogen (RON) species including NOx, $\mathrm{OH}, \mathrm{O}$, and $\mathrm{O3}$. The plasma formed in an electric discharge is known as corona incandescent discharge plasma RON produced from cold atmospheric-pressure plasma can activate phytosensor and phytoactuator signaling molecules for surface modification processes and support water absorption by seeds (Holdsworth et al., 2008). The effect of plasma on seed characteristics can increase the hydrophilic ability of seeds to increase water absorption (Junior et al., 2016). The micropyle and hilum are the main areas that play a role in imbibition. Micropyle has thick endothelial cell which can expand and increase water absorption. Hilum consists of a palisade cell layer bounded externally by subcuticular tissue as well as an extra-hilar layer adjacent to the palisade layer (transverse subcuticular layer) and a more external cuticle layer, when treated with plasma the micropyle and hilum are altered; hilum can increase the amount of water absorbed, and the micropyle shows a more open configuration, so it has a greater contribution than seeds without plasma irradiation (Junior et al., 2016)..

Based on the results of this study, the garlic seeds which experience dormancy for 6-7 months, its dormancy can be broken at the age of 3 months after harvest by using the corona incandescent plasma radiation method. This means that at the age of 3 months, the garlic seeds can be cultivated without having to store them for 6-7 months.

\section{CONCLUSION}

Based on the research that has been done, it can be concluded that plasma radiation treatment provides a significant difference in the germination percentage; meanwhile storage temperature is not significantly different. Based on the research that has been done, it can be ignored that plasma radiation treatment provides a significant difference in the proportion of germination and length of sprouts; Meanwhile, the storage temperature was not significantly different. plasma radiation 15-30 minutes of most optimal duration. plasma radiation for 15 minutes showed the highest sprouts length of $12.97 \mathrm{~cm}$. Plasma radiation treatment for 30 minutes is the most optimal treatment with a germination proportion of $74 \% .0 \mathrm{~min}$ radiation yielded the lowest proportion of germination and germination length.

\section{SOURCES OF FUNDING}

This research received no specific grant from any funding agency in the public, commercial, or not-for-profit sectors.

\section{CONFLICT OF INTEREST}

The author have declared that no competing interests exist.

\section{ACKNOWLEDGMENT}

The researchers would like to thank the supervisor from the Master Study Program of Biology, Faculty of Science and Mathematics, Diponegoro University for research guidance with funds sourced from the Directorate of Research and Community Service Deputy of Research Strengthening and Development.

\section{REFERENCES}

[1] Chen, S.-Y., Chou, S.-H., Tsai, C.-C., Hsu, W.-Y., Baskin, C. C., Baskin, J. M., ... Kuo-Huang, L.-L. (2015). Effects of moist cold stratification on germination, plant growth regulators, metabolites and embryo ultrastructure in seeds of Acer morrisonense (Sapindaceae). Plant Physiology and Biochemistry, 94, 165-173. https://doi.org/10.1016/j.plaphy.2015.06.004 
The Effect of Corona Incandescent Plasma Radiation and Storage Temperature on The Viability of Garlic Seeds (Allium Sativum L. Lumbu Kuning Variety)

[2] Graeber, K., Linkies, A., Muller, K., Wunchova, A., Rott, A., \& Leubner-Metzger, G. (2010). Cross-species approaches to seed dormancy and germination: conservation and biodiversity of ABA-regulated mechanisms and the Brassicaceae DOG1 genes. Plant Molecular Biology, 73(1-2), 67-87. https://doi.org/10.1007/s11103-009-9583-x

[3] Holdsworth, M. J., Bentsink, L., \& Soppe, W. J. J. (2008). Molecular networks regulating Arabidopsis seed maturation, after- ripening, dormancy and germination Author. New Phytologist, 179, 33-54. https://doi.org/doi.org/10.1007/s11103-009-9583-x

[4] Junior, C. A., Vitoriano, J. de O., Silva, D. L. S. da, Farias, M. de L., \& Dantas, N. B. de L. (2016). Water uptake mechanism and germination of Erythrina velutina seeds treated with atmospheric plasma. Nature Publishing Group, 6(September), 1-7. https://doi.org/10.1038/srep33722

[5] Kordas, L., Pusz, W., Czapka, T., \& Kacprzyk, R. (2015). The Effect of Low-Temperature Plasma on Fungus Colonization of Winter Wheat Grain and Seed Quality. Environmental, 24(1), 433-438.

[6] Kucera, B., Cohn, M. A., \& Leubner-metzger, G. (2005). Plant hormone interactions during seed dormancy release and germination. Seed Biology, 15, 281-307. https://doi.org/10.1079/SSR2005218

[7] Lesilolo, M. K., Riry, J., \& Matatula, E. (2013). Pengujian viabilitas dan vigor benih beberapa jenis tanaman yang beredar di pasaran kota ambon. Agrologia, 2(1), 1-9. https://doi.org/doi.org/10.30598/a.v2i1.272

[8] Lewak, S. (2011). Metabolic Control of Embryonic Dormancy in Apple Seed: Seven Decades of Research. Acta Physiology Plant, 33, 1-24. https://doi.org/10.1007/s11738-010-0524-8

[9] Li, S., Jimenez, J. A. M., Hessel, V., \& Gallucci, F. (2018). Recent Progress of Plasma-Assisted Nitrogen Fixation Research: A Review. Multidisciplinary Digital Publishing Institute, 6(12), 1-25. https://doi.org/10.3390/pr6120248

[10] Ling, L., Jiangang, L., Minchong, S., Jinfeng, H., Hanliang, S., Yuanhua, D., \& Jiafeng, J. (2016). Improving Seed Germination and Peanut Yields by Cold Plasma. Plasma Science and Technology, 18(10), 1027-1033. https://doi.org/10.1088/1009-0630/18/10/10

[11] Rahman, M. H., Haque, M. S., \& Ahmed, M. (2003). Pre-planting temperature treatments for breaking dormancy of garlic cloves. Plant Sciences, 2(1), 123-126.

[12] Rosniawaty, S., Anjarsari, I. R. D., \& Sudirja, R. (2018). Aplikasi sitokinin untuk meningkatkan pertumbuhan tanaman teh di dataran rendah. Industrial and Beverage Crops, 5(1), 31-38.

[13] Sari, W., \& Faisal, M. F. (2017). Pengaruh Media Penyimpanan Benih Terhadap Viabilitas dan Vigor Benih Padi Pandanwangi. Agroscience, 7(2), 300-310.

[14] Shaban, M. (2013). Study on some aspects of seed viability and vigor. International Journal of Advanced Biological and Biomedical Research, 1(12), 1692-1697.

[15] Shu, K., Liu, X., Xie, Q., \& He, Z. (2016). Two Faces of One Seed: Hormonal Regulation of Dormancy and Germination. Molecular Plant, 9(1), 34-45. https://doi.org/10.1016/j.molp.2015.08.010

[16] Sulassih, Purwanto, Y. A., Naibaho, N., Pratama, S. Y., \& Nurmalia. (2018). Viabilitas Benih Bawang Putih Varietas Tawang Mangu Setelah Penyimpanan pada Berbagai Suhu Viabilitiy of Allium sativum cv. Tawang Mangu Seed After Storage at Different Storage. Hortikultura, 2(3), 43-47. https://doi.org/http://dx.doi.org/10.29244/chj.2.3.43-47

[17] Volkov, A. G., Hairston, J. S., Patel, D., Ryan, P., \& Xu, K. G. (2019). Cold plasma poration and corrugation of pumpkin seed coats Alexander. Bioelectrochemistry, 128, 175-185. https://doi.org/10.1016/j.bioelechem.2019.04.012

[18] Wicaksono, M. I., Rahayu, M., \& Samanhudi. (2014). Pengaruh Pemberian Mikoriza dan Pupuk Organik Terhadap Pertumbuhan Bawang Putih. Caraka Tani, 29(1), 35-44.

[19] Woldeyes, F., Kebede, W., \& Tabor, G. (2017). Emergence of Garlic (Allium sativum L.) as Influenced by Low Storage Temperature and Gibberellic Acid Treatments. Agriculture and Ecology Research, 10(2), 1-7. https://doi.org/10.9734/JAERI/2017/29843

[20] Yeol, S., Warpeha, K. M., \& Huber, S. C. (2019). The brassinosteroid receptor kinase, BRI1, plays a role in seed germination and the release of dormancy by cold strati fi cation. Journal of Plant Physiology, 241(October 2018), 1-8. https://doi.org/10.1016/j.jplph.2019.153031

[21] Zhao, Y. (2010). Auxin biosynthesis and its role in plant development. Plant Biology, 61, 49-64. https://doi.org/10.1146/annurev-arplant-042809-112308.Auxin 
Febiasasti Trias Nugraheni, Erma Prihastanti, and Endah Dwi Hastuti

[22] Zheng, J., Chen, F., Wang, Z., Cao, H., Li, X., Deng, X., ... Liu, Y. (2012). A novel role for histone methyltransferase KYP / SUVH4 in the control of Arabidopsis primary seed dormancy. New Phytologist, 193, 605-616. https://doi.org/doi.org/10.1111/j.1469-8137.2011.03969.x

[23] Zhou, R., Zhou, R., Zhang, X., Zhuang, J., Yang, S., Bazaka, K., \& Ostrikov, K. (Ken). (2016). Effects of Atmospheric-Pressure N2, He, Air, and 02 Microplasmas on Mung Bean Seed Germination and Seedling Growth. Nature Publishing Group, 6(September), 1-11. https://doi.org/10.1038/srep32603. 